\title{
Students' Views on the Use of WhatsApp during Covid-19 Pandemic: A Study at IAIN Batusangkar
}

\author{
Sirajul Munir ${ }^{1}$, Rita Erlinda ${ }^{2}$, Hanif Afrinursalim ${ }^{3}$ \\ ${ }^{1}$ IAIN Batusangkar, Indonesia.e-mail: sirajulmunir@iainbatusangkar.ac.id \\ 2IAIN Batusangkar, Indonesia.e-mail: ritaerlinda@iainbatusangkar.ac.id \\ 3IAIN Batusangkar, Indonesia.e-mail: hanifafrinursalim@gmail.com
}

\begin{tabular}{|c|c|}
\hline ARTICLE INFO & ABSTRACT \\
\hline $\begin{array}{l}\text { DOI: } \\
\text { http://dx.doi.org/10.21093 } \\
\text { /ijeltal.v5i2.740 }\end{array}$ & $\begin{array}{l}\text { This study aims to describe students'views on the use of WhatsApp in English } \\
\text { Teaching Department classes during the covid-19 pandemic. The impact of } \\
\text { the Coronavirus disease } 2019 \text { (Covid-19) pandemic is now beginning to spread } \\
\text { to the world of education. This condition makes the students and the lecturers } \\
\text { used online media or online learning much longer than expected. In the online } \\
\text { learning process, WhatsApp is one of the most used applications. This study } \\
\text { used qualitative research. The research population was all } 270 \text { students of the } \\
\text { English Teaching Department of IAIN Batusangkar. The sample involved } 168 \\
\text { students by using stratified random sampling technique. Slovin's formula was } \\
\text { used to measure the sample. The research instrument was questionnaires. It } \\
\text { was designed in the type of closed-ended and open-ended forms. The } \\
\text { questionnaire consisted of } 21 \text { statements. Then, to analyze the data from a } \\
\text { closed-ended questionnaire, the researchers used Guttman Scale. } \\
\text { Meanwhile, to analyze the open-ended questionnaire, the researchers } \\
\text { classified students' responses and then described the results. The finding of } \\
\text { the study indicated that students' views on the use of WhatsApp (WA) in } \\
\text { English Teaching Department classes during the covid-19 pandemic mostly } \\
\text { positive (73.2\%) and the negative responses only (26.8\%). Furthermore, } \\
\text { students' views on the use of WA includes WA as media in doing online } \\
\text { learning process; WA as an educational media; WA as an evaluation and } \\
\text { assessment benchmarks; WA as an application of sharing information; WA as } \\
\text { the application to do group discussion; and WA as media to increase literation } \\
\text { and to share learning materials. This research implies that WA could be used } \\
\text { to do the online learning process because it empirically helps the students to } \\
\text { get enthusiastically involved in learning activities. }\end{array}$ \\
\hline
\end{tabular}

How to cite:

Munir, S., Erlinda, R., Afrinursalim, H. (2021). Students' Views on the Use of WhatsApp during Covid-19 Pandemic: A Study at IAIN Batusangkar. Indonesian Journal of English Language Teaching and Applied Linguistics, 5(2), 323-334

\section{Introduction}

The impact of the Coronavirus disease 2019 (Covid-19) pandemic is now beginning to spread to the world of education. This is achieved as an attempt to prevent the unfold of Covid-19 transmission. It is was hoping that every one academic establishment will now no longer 
perform activities as usual; this will decrease the unfold of Covid-19. The equal component has been achieved by diverse international locations which are uncovered to this disease, lockdown or quarantine regulations performed that allows you to lessen the interplay of many humans who can offer get admission to the to unfold of the Covid-19. By the growing of coronavirus instances in Indonesia, the authorities have determined to enforce online mastering in all stages of education. This system is implemented to minimize the spreading of coronavirus and to maximize the teaching and learning process. This system is carried out to decrease the spreading of coronavirus and to maximize the teaching, and to get to know the technique. This system can replace the conventional system in teaching and getting to know technique which behaviour a teaching activity without any direct interaction among the students and teachers.

This situation forces the lecturers and the students to use online media or online learning much longer than expected. Meanwhile, the students and lecturers are still not ready to face up this situation. Harida (2020: 25) states that Online learning is learning that supports the new era of 4.0 industries. The use of online platforms becomes challenging in the 4.0 industrial revolution nowadays (Ariyanti, 2020:168; Sari, 2020: 350; and Fauzan \& Nadia, 2021: 102). Unfortunately, it happens in a very bad condition of the situation in Indonesia nowadays. Because of the broad case of Corona Viruses Disease 2019 (Covid-19), the students must force to study using online learning, although they are not ready to use it well. They must follow the regulations to support their learning becomes run as usual. WhatsApp is one of the applications which lecturers usually used for teaching in this Covid-19 pandemic. WhatsApp, as a matter of fact, is not an application which purposively used for education. It is just a message application which has many features such as group, text message, audio message, video call, etc. But in this covid-19 pandemic, many lecturers used WhatsApp as the application in the virtual classroom. The use of WhatsApp in teaching activities is based on several reasons: (1) easy to use; (2) consume less of package data; and (3) has many useful features such as group, audio message, video call, and voice note.

Experts and practitioners state some arguments regarding on the use of WhatsApp application in education. Cetinkaya (2017) in Nurazizah, Frihatin, \& Sugiarto (2019:345), for example, clearly emphasize that there are a lot of instant messaging applications that can operate on mobile devices. It is seen that WhatsApp application is one of the most favoured mobile-based applications. WhatsApp is a social media application which is used widely today. In the field of education, it could be used as a part of mobile learning to improve language proficiency. Higher learning institutions have been using WhatsApp as a medium of communication between students and their lecturers. WhatsApp presents itself as one of the inventive teaching methods that can attract students and provide them with opportunities for further learning. WhatsApp helps students to work smarter and more effectively. Lestiyanawati (2020:75) argues that in conducting e-learning, some information and technology products can be utilized in supporting the online classroom. She also states that the first supported application to accommodate e-learning is WhatsApp. It is unpaid, mostly used chatting application. WhatsApp is effective in increasing success in learning, developing students' positive views toward the use of WhatsApp in courses. However, the previous research from Burhoumi (2015:235) convinces that WhatsApp mobile application only effective to pursue learning activities if the teachers do it in a blended course integrating both faces to face learning and mobile learning. This research is intended to describe the following 
research question: What are the students' views on the use of WhatsApp application in English teaching Department classes during the Covid-19 pandemic?

\section{Theoretical framework}

\subsection{Online Learning}

Online learning is perceived as the utilization of the internet as having access to materials, having interaction with contents, teachers, and other students, and gaining help in getting to know the process to gain knowledge, make meaning, and progress through learning experience (Ally in Nugroho, 2020:53). Online learning is defined as learning carried out from a distance assisted by electronic devices, for instance, laptops, tablets, smartphones, and personal computers, which require an internet connection (Gonzalez \& Louis, 2018:1). Fauzan \& Nadia (2021:104) claim online learning is an effective media for students. Furthermore, Raad (2020) states that online learning has successfully helped students learn in homes during the COVID-19 pandemic and using various applications such as Zoom, Teams, Veeva, and Google Classroom, and many others. These ideas could be concluded that online learning is a teaching and learning system that utilizes electronic media specifically the utilization of internet in accessing materials; having interaction with contents, teachers, and other students; and gaining assistance in learning process to get knowledge, make meaning, and progress through learning experience.

\subsection{WhatsApp}

According to Nurazizah et al. (2019:345), WhatsApp is a tool to communicate with other people through instant messaging. People who use WhatsApp could send various information like text messages, documents, videos, audios, and images. Meanwhile, La Hanisi, Risdiany, Dwi Utami, \& Sulisworo (2018:31) defined that WhatsApp as a smartphoneand web-based instant message application that allows users to exchange information using many kinds of media, including text, image, video, and audio messages. In conclusion, WhatsApp is a message application that the users could install on the smartphone, which is a free, convenient, easy to use, fast, personal mode of communication. WhatsApp allows its users to use their Internet connection to send messages to each other and have many features that could help the users such as various file format, text messages, documents, videos, audios, and images

\subsection{WhatsApp Functions in Online Learning during Covid-19 Pandemic.}

No one can deny the fact that WhatsApp yields several functions in online learning during the covid-19 pandemic.

\subsubsection{WhatsApp as media in doing online learning process}

WhatsApp can be used as the media to do the online learning process. Initially, the teacher gave material to the students in the group, then the lecturers gave orders to do questions or have an opinion about the material. When students express their ideas or opinions, they must be filled in with names and numbers that are absent, which provide information to all students who provide information to all students directly. Students could deliver their responses freely, and the lecturer responds to students' inquiries and comments, starts new issues, or posts queries. WhatsApp helps the students to get enthusiastically involved in learning activities via various features on this application (Sahidillah \& Miftahurrisqi, 2019). 


\subsubsection{WhatsApp as an education media}

WA in education helps to encourage learners to anticipate needs, make collaborative learning efficient and effective, and build a relationship that encourages learner-to-learner for reliable and advanced learning. Lecturers can use WA as a means of controlling student attitudes. Student attitudes can be formed through multidimensional communication. For example, when a dirty message is thrown, the teacher can immediately reprimand and correct it.

\subsubsection{WhatsApp as an evaluation and assessment benchmarks related to the learning outcome}

WhatsApp can also be used as a means of evaluating students, including evaluating learning activities, evaluating learning outcomes, and evaluating students' attitudes during the distance learning process

\subsubsection{WhatsApp as an application to sharing information}

WA can also be used as an application to share information, especially in the current pandemic conditions. The flow of information is very fast-changing. WA allows users to exchange information using a variety of media, including text, image, video, and audio messages (Shodiq \& Zainiyati, 2020).

\subsubsection{WhatsApp as the application to do group discussion related to the learning activity.}

The wider discussion opportunities with optimizing the use of WA can increase students' enthusiasm for learning. It is also because WA has a group chat feature that allows the students to have a group discussion. The group discussion also will run better with a variety of features.

\subsubsection{WhatsApp as media to increase literation and to share learning material}

WA can be used for sharing learning material because WA has a feature that can save documents in the form of pdf, Microsoft word, excel, and PowerPoint. The availability of the option to share lecture materials can increase learning and discussion opportunities for students wherever and whenever.

\subsubsection{WhatsApp as a tool to take students attendance}

The finding of Suyudi, Khusaini, Sugiyanto, \& Winarto (2017) that displayed by their observation on the track record of conversations on WA, the attendance information from lectures can be conveyed by students through Group WA of the courses, and some can be delivered personally through lecturers' personal WA.

\section{Research Methodology}

This present research used a quantitative method. The research was designed to describe the present condition of the research subjects (Gay, 1990). The research was intended to present data and a clean instance approximately the social state of affairs with the goal of descriptive studies. In this example, the factor of descriptive studies is to gather and collect the simple facts in a descriptive manner or its purpose to make the description of the students' views on the use of WhatsApp in English Teaching Department classes during the Covid-19 pandemic. This research was conducted at IAIN Batusangkar, especially the students of the English Teaching Department who used WhatsApp in their classes during the covid-19 pandemic. 
The research population were 270 students from the second semester, the fourth semester, the sixth semester, and the eight-semester students of the English Teaching Department. The sampling technique used Slovin's formula. It involved 186 respondents using stratified random sampling technique.

In answering the research question, the researchers used a questionnaire. A questionnaire was an instrument in the form of questions or statements. It was distributed to the participants of a certain study in order to obtain the participants' responses. The questionnaire used was designed in the type of closed-ended and open-ended forms. The format used in the closed-ended form of a questionnaire is the Guttman Scale. In the openended form, the questions gave opportunities for the participants to share and express their feelings and views freely without options provided towards the use of WhatsApp application in English Teaching Department classes during the covid-19 pandemic. Both of the closedended and open-ended forms of the questionnaire were aimed to investigate the students' views on the use of WhatsApp application in English Teaching Department classes during the covid-19 pandemic.

To analyze the closed-ended questionnaire, the researchers used the following formula in calculating the percentages:

$$
\mathrm{P}=\frac{\sum \chi}{\sum \mathrm{n}} \times 100 \%
$$

In which,

$\mathrm{P}=$ The percentage of the result

$\Sigma \chi=$ The numbers of participants based on the degree of agreement

$\Sigma \mathrm{n}=$ The numbers of participants

To analyze the open-ended questionnaire, the researchers classified students' responses and described the result.

\section{Findings}

The results of the research show that students have a view on the use of WhatsApp in learning. To be more detail, it could be described as follows:

\subsection{WhatsApp as media in doing online learning process}

\begin{tabular}{|l|c|c|c|c|}
\hline Indicator & Answer & $\boldsymbol{\Sigma}$ X & $\boldsymbol{\Sigma} \mathbf{N}$ & Percentage \\
\hline $\begin{array}{l}\text { Students have an opinion that WhatsApp is a } \\
\text { good media to do online learning process } \\
\text { during the covid-19 pandemic }\end{array}$ & Yes & 168 & 92 & $73.2 \%$ \\
\cline { 2 - 5 } & No & 167 & 92 & $26.8 \%$ \\
\hline
\end{tabular}

The table shows that students view WA as media to do online learning process during the covid-19 pandemic. This is indicated by students' responses that WA is a media that effective enough to do online learning process during the Covid-19 pandemic because there were 123 respondents or $73.2 \%$ of the total percentage who agreed that WA is good media in online learning, while just 45 respondents or $26.8 \%$ of total percentage who disagreed with it. It 
means that most of the students perceived that WA is a good media to do online learning process during the covid-19 pandemic.

The students who agreed with WA as a good media of online learning stated the following reasons: effective and easy to use, the features of WA are helpful, save internet quota, the application is very light, make the lecturer easier to observe the students, and make the communication between lecturer and students run smoothly. However, the students who disagreed with that ideas stated the following reasons: member capacity in the group is limited, make the students easy to do cheating, the upload size of the file is limited, and old chats are easily piled up by new chats.

\subsection{WhatsApp as an education media}

\begin{tabular}{|l|c|c|c|c|}
\hline Indicator & Answer & $\Sigma \mathbf{X}$ & $\Sigma \mathbf{N}$ & Percentage \\
\hline $\begin{array}{l}\text { Students view WhatsApp as a good education } \\
\text { tool during the covid-19 pandemic }\end{array}$ & Yes & 123 & 168 & $73.2 \%$ \\
\cline { 2 - 5 } & No & 45 & 167 & $26.8 \%$ \\
\hline
\end{tabular}

As can be seen from the table above, the students view WA as an education media during the covid-19 pandemic. Based on the questionnaire that the researcher gave to the students of the English teaching department of IAIN Batusangkar, it proved that most of the students taught that WA is a good media of education. It was seen from 123 respondents, or $73.2 \%$ of the total percentage agreed with the statement, and only 45 respondents or $26,3 \%$ who disagreed with it. This finding indicates that most of the students view WA as a good education tool during the Covid-19 pandemic.

The students who agreed to WhatsApp as good education media stated the following reasons: many features in the applications, make the communication between student and lecturer easier to avoid miscommunication, easier to sharing learning material and knowledge, consumed less internet quota, commonly used, and could be accessed anywhere. But the students who disagreed also have their reasons: it easier to do face-to-face learning, it easier for the students to lose their focus in the learning process, the uploaded file size is limited, and old gen smartphone is not supported.

\subsection{WhatsApp as an evaluation and assessment benchmarks related to the learning outcome}

\begin{tabular}{|l|c|c|c|c|}
\hline \multicolumn{1}{|c|}{ Indicator } & Answer & $\Sigma \mathbf{X}$ & $\Sigma \mathbf{N}$ & Percentage \\
\hline $\begin{array}{l}\text { Students view WhatsApp as a good application } \\
\text { to do evaluation and assessment during the } \\
\text { covid-19 pandemic }\end{array}$ & Yes & 97 & 168 & $57.7 \%$ \\
\cline { 2 - 5 } & No & 71 & 168 & $42.3 \%$ \\
\hline
\end{tabular}

The table above regarded students' views on evaluation and assessment benchmarks related to the learning outcome during the covid-19 pandemic. Most of the students disagreed that WA is a good benchmark to do evaluation and assessment. It proved with 97 respondents, or $57.7 \%$ of the total percentage, disagreed with the statement of WA is a good media for evaluation and assessment. It means that the students thought that WA is not a really effective application to do evaluation and assessment in online learning during the Covid-19 pandemic. 
The students who disagreed with WhatsApp as a good evaluation and assessment benchmarks related to the learning outcome during the covid-19 pandemic stated the following reasons: better to use another application that is easy to make an assessment. It is not effective and efficient in assessment. Many students copy-paste the assignment, upload file size is limited, and cannot measure students' true abilities and potential. The students who agreed stated the following reasons: the lecturers could check when the student send the assignment, the lecturers could check students' participation during the online learning process, it is flexible and not complicated, the lecturers could immediately inform the assessment of the students, and the lecturers could give the feedback of the assessment immediately in oral or written.

\subsection{WhatsApp as an application to share information}

\begin{tabular}{|l|c|c|c|c|}
\hline \multicolumn{1}{|c|}{ Indicator } & Answer & $\boldsymbol{\Sigma} \mathbf{X}$ & $\boldsymbol{\Sigma} \mathbf{N}$ & Percentage \\
\hline $\begin{array}{l}\text { Students have an opinion that WhatsApp is a } \\
\text { good application to share information during } \\
\text { the covid-19 pandemic }\end{array}$ & Yes & 167 & 168 & $99.4 \%$ \\
\cline { 4 - 5 } & No & 1 & 168 & $0.3 \%$ \\
\hline
\end{tabular}

The table above showed that the students' views on WA as an application to share information during the covid-19 pandemic. In the questionnaire which the researchers gave to the students of the English teaching department of IAIN Batusangkar. It displayed that 167 respondents agreed that WA is a good application in sharing information especially related to the learning activity, and there was just one student who disagreed with that statement. It means $99.4 \%$ of total respondents have a good impression of WA as an application to share information especially related to the learning process during the covid-19 pandemic.

The students who agreed that WhatsApp is a good media to share information stated the following reasons: information related to lectures spread quickly in WhatsApp., almost all of the students have WhatsApp in their smartphone, easily connected and communicate each other. The information could forward to others contact easily, many useful features in sharing information, and could work in weak connection. There is one student who disagreed, but the reason that he stated was not clear.

\subsection{WhatsApp as the application to do group discussion related to the learning activity}

\begin{tabular}{|l|c|c|c|c|}
\hline \multicolumn{1}{|c|}{ Indicator } & Answer & $\boldsymbol{\Sigma} \mathbf{X}$ & $\mathbf{\Sigma N}$ & Percentage \\
\hline $\begin{array}{l}\text { Students view WhatsApp as a good application } \\
\text { to do group discussion during the covid-19 } \\
\text { pandemic }\end{array}$ & Yes & 133 & 168 & $79.2 \%$ \\
\cline { 2 - 5 } & No & 35 & 168 & $\mathbf{2 0 . 8 \%}$ \\
\hline
\end{tabular}

The table shows students' views on WA as an application to do group discussion during the Covid-19 pandemic. Based on the questionnaire answered by the students of the English teaching department of IAIN Batusangkar, it means that most of the students think WA is also an effective media to do group discussion. It is because 133 respondents, or $79.2 \%$ of the total percentage, agreed with the statement, and 35 respondents disagreed or 20.8 of the total percentage. It indicated that most of the students have a believe that WA is a good application to do group discussions related to learning assignments during the covid-19 pandemic. 
The students who agreed stated the following reasons: the features of WhatsApp such as Group, Voice Note, Voice Call, and Video-Call support the students to do online discussion, make it easier for students to have discussions between students and between students and lecturers, consumed less internet quota, and the information related to learning material spread quickly. The students who disagree also have their reasons: WhatsApp is not efficient because not all the members join the discussion and Need another supported application.

\subsection{WhatsApp as media to increase literation and to share learning material}

\begin{tabular}{|l|c|c|c|c|}
\hline \multicolumn{1}{|c|}{ Indicator } & Answer & $\Sigma \mathbf{X}$ & $\boldsymbol{~} \mathbf{N}$ & Percentage \\
\hline $\begin{array}{l}\text { Students have an opinion that WhatsApp is a } \\
\text { good media to increase literation and to share } \\
\text { learning material during the covid-19 pandemic }\end{array}$ & Yes & 149 & 168 & $88.7 \%$ \\
\cline { 4 - 5 } & No & 19 & 168 & $11.3 \%$ \\
\hline
\end{tabular}

The table above displayed the students' opinion on WA as a media to increase the literation and sharing learning material during the covid-19 pandemic. In the questionnaire that the researcher shared with the students of the English teaching department of IAIN Batusangkar, it proved that most of the students believe that WA is a good application as media of literation and sharing material. It is because there were 149 respondents who agree with the statement or $88.7 \%$ of the total percentage. Meanwhile, only 19 respondents disagree or $11.3 \%$ total percentage. It means that the students agreed that WA is a good application to increase their literation related to learning and also make them easy to share learning material during the covid-19 pandemic.

The students who agreed stated the following reasons: easy to use because WhatsApp supports sending various file formats such as word, excel, pdf, video, photo, etc., many information the students could get from the application, consumed fewer internet data, the process of sending learning material is faster than any application, the group feature on WhatsApp makes it easy to spread information from one person to many people, it could be connected to the laptop, and the downloaded material files on WhatsApp can be saved directly to smartphone storage. The students who disagreed also have their own reasons: the upload file size is limited, the connection problem, and sometimes the learning material piled up by new chats.

\section{Discussion}

This part presents the discussion of the research findings. As previously stated, the research finding showed that WA is a good learning media during the Covid-19 pandemic. It was proven by the students' opinion on the use of WA application in English Teaching Department classes during the covid-19 pandemic.

From the finding, it was clearly stated that the students mostly have an opinion that WA is a good media to do online learning process during the covid-19 pandemic. The students who agreed with WA is a good media of online learning stated the following reasons: effective and easy to use, the features of WA is helpful, save internet quota, the application is very light, make the lecturer easier to observe the students, and make the communication between lecturer and students smoothly. It is relevant with Sahidillah \& Miftahurrisqi (2019), who stated that WA could be used as media of learning because it has many features that could support the learning process, such as group, voice-note, video call, etc. This is also to support 
Mbukusa's (2018) idea, which showed WA is one of the very good resourceful teaching methods which allows the students to express their thoughts and ideas via various features of the WA. It also supports Dhahir's research (2020) which showed that WA has proven to be quite useful for online teaching and learning.

The next finding is the students also have an opinion that WA is a good education media. The students who agree on WhatsApp as a good education tool stated the following reasons: many features in the applications, make the communication between student and lecturer easier to avoid miscommunication, easier to sharing learning material and knowledge, consumed less internet quota, commonly used, and could be accessed anywhere. The finding confirmed the similar research done by Hamid (2020), who claims that students have a positive perception of online learning during the Covid-19 Pandemic. The finding also clearly supports the idea of Shodiq \& Zainiyati (2020), who said the lecturers could use WA as media of education because student attitudes can be formed through multidimensional communication. For example, when a dirty message is thrown, the teacher can immediately reprimand and correct it. Yalcinalp and Gulbahar (2010) also stated that WA in education helps to encourage learners to anticipate needs, make collaborative learning efficient and effective, and build relationship that encourages learner-to-learner for reliable and advanced learning. The finding also supports Plana et al. research (2013) which clearly states that the instant messaging application WhatsApp increases students' motivation and willingness to study in immersion programs.

The other finding is the students have good views on WA as an application to sharing information during the covid-19 pandemic. The students who agreed that WA is a good media for sharing information stated the following reasons: information related to lectures spread quickly in WA, almost all of the students have WA on their smartphone, easily connected and communicate with each other. The information could be forwarded to other contacts easily, many useful features in sharing information, and it could work in weak connection relevant with the statement of Shodiq \& Zainiyati (2020), which stated that WA could also be used as an application to share information especially in the current pandemic conditions the flow of information is very fast-changing. The finding is also supported by the statement of La Hanisi, Risdiany, Dwi Utami, \& Sulisworo (2018), WA is a smartphone-and web-based instant message application that allows users to exchange information using a variety of media, including text, image, video, and audio messages.

The next finding is the student have a good opinion about WA as a media to do the group discussion related to the learning process. The students who agreed that WhatsApp is a good media to do group discussion stated the following reasons: the features of WhatsApp such as Group, Voice Note, Voice Call, and Video Call support the students to do online discussion, make it easier for students to have discussions between students and between students and lecturers, consumed less internet quota, and the information related to learning material spread quickly. It is supported by Kukulska-Hulme, Norris, \& Donohue (2015), who stated that the wider discussion opportunities with optimizing the use of WA could increase students' enthusiasm for learning. It also because WA has a group chat feature that allows the students to have a group discussion. The group discussion also will run better with a variety of features (La Hanisi et al., 2018). 
The other finding is most of the students have an opinion that WA is a good media to increase their literation and sharing learning material. The students who agree that WhatsApp is a good media of literation and sharing learning material stated the following reasons: easy to use because Whatsapp supports sending the various file, consumed less internet data, the process of sending learning material is faster than any application, the group feature on WhatsApp makes it easy to spread information from one person to many people, and the downloaded material files don Whatsapp can be saved directly to smartphone storage. It relevant to the finding of (Suyudi et al., 2017), who showed that WA could be used for sharing learning material because WA has a feature that can save documents in the form of pdf, Microsoft word, excel, and PowerPoint. This finding relevant to Centinkaya's research (2017) which displayed that students developed positive opinions towards the use of WhatsApp in their courses.

The further finding is the students have a good opinion about WA as an application to take the students' attendance. The students who agreed that WhatsApp is a good media to take students attendance have some reasons: make it easier for students to state their attendance in lectures such as making an attendance list, very fast and efficient, could work in weak connection and can see the timeliness of students taking absence. It is supported by the finding of Suyudi et al. (2017) that displayed by their observation on the track record of conversations on WA, the attendance information from lectures can be conveyed by students through Group WA of the courses, and some can be delivered personally through lecturers' personal WA. The last finding is the students disagreed that WA as the benchmarks of the evaluation and assessment related to the learning outcome. The students who disagreed stated the following reasons: better to use another application that is easy to make an assessment, it is not effective and efficient in assessment, many students that copy-paste the assignment, upload file size is limited, and cannot measure students' true abilities and potential. It means this finding rejected the previous research of Shodiq \& Zainiyati (2020) stated that WA could also be used for evaluating students, including evaluating learning activities, evaluating learning outcomes, and evaluating students' attitudes during the distance learning process.

\section{Conclusion}

This research concludes that the students' views on the use of WhatsApp in English Teaching Department classes during the covid-19 pandemic are very good. Especially they agreed that WhatsApp is good as media to do online learning process, education media, application to sharing information during the covid-19 pandemic, to do the group discussion related to the learning process, to increase their literation and sharing learning material. Students, however, disagreed that WhatsApp as the benchmark of the evaluation and assessment related to the learning outcome. The implication of this research is WhatsApp could be used to do the online learning process because it empirically helps the students to get enthusiastically involved in learning activities. For future researchers who want to do research related to this topic, there are several related things that can be developed from this research. Future researchers can get further into the students' perception toward the implementation of WA in Speaking class. Future researchers also can do research on the problems faced by the students in using WhatsApp in learning. 


\section{References}

Ariyanti, A. (2020). EFL Students' Challenges towards Home Learning Policy During Covid-19 Outbreak. Indonesian Journal of English Language Teaching and Applied Linguistics, 5(1). Retrieved from https://ijeltal.org/index.php/ijeltal/article/view/649

Burhoumi, C. (2015). The Effectiveness of WhatsApp Mobile Learning Activities Guided by Activity Theory on Students' Knowledge Management. Contemporary Educational Technology, 6(3), 221-238.

Cetinkaya, L. (2017). The Impact of Whatsapp Use on Success in Education Process. The International Review of Research in Open and Distributed Learning. Retrieved from 18. 10.19173/irrodl.v18i7.3279.

Dhahir, D. (2020). The usability of whatsapp messenger as online teaching-learning media. Journal of Information Technology and Its Utilization, 3. Retrieved from 48. 10.30818/jitu.3.2.3629.

Fauzan, U. \& Nadia, N. (2021). The Reformation Discourse of Internet-Based Learning of Madrasah Aliyah English Teachers in Kalimantan,, Volume 28 Issue 1.3 February 2021. https://www.asian-efl-journal.com/monthly-editions-new/2021-monthly-

edition/volume-28-issue-1-3-february-2021/. The Asian EFL Journal, 28(1). Retrieved from https://www.asian-efl-journal.com/monthly-editions-new/2021-monthlyedition/volume-28-issue-1-3-february-2021/

Gay, L. R. (1990). Educational Research:Competencies for Analysis and Applications. Third Edition. Ohio: Merrill Publishing Company.

Gonzalez, D., \& Louis, R. St. (2018). Online Learning. J. I. Liontas (Ed.), The TESOL Encyclopedia of English Language Teaching (1st Ed.). Retrieved from https://doi.org/10.1002/9781118784235.eelto423

Hamid, S. M. (2020). Online Digital Platforms During COVID-19 in EFL Clases: Visual Impairment StdentT'Perception. ETERNAL, 6(2).

Harida, E. S. (2020). Students' Learning in Corona Virus Diseases 2019 (Covid-19) Situation. English Journal for Teaching and Learning, 08(01), 25-37.

La Hanisi, A., Risdiany, R., Dwi Utami, Y., \& Sulisworo, D. (2018). The Use of WhatsApp in collaborative learning to improve English teaching and learning process. International Journal of Research Studies in Educational Technology, 7(1). Retrieved from https://doi.org/10.5861/ijrset.2018.3004

Lestiyanawati, R. (2020). The Strategies and Problems Faced by Indonesian Teachers in Conducting e-learning during COVID-19 Outbreak. CLLIENT (Culture, Literature, Linguistics, English Teaching), 2(1), 71-82.

Mbukusa, N. R. (2018). Perceptions of Students on the Use of WhatsApp in Teaching Methods of English as Second Language at the University of Namibia. Journal of Curriculum and Teaching, VII(2). Retrieved from https://doi.org/10.5430/jct.v7n2p112

Nugroho, A. (2020). EFL Classes Must Go Online! Teaching Activities and Challenges during COVID-19 Pandemic in Indonesia. Register Journal, 13, 49-76. Retrieved from 10.18326/rgt.v13i1

https://www.researchgate.net/publication/341750033_EFL_Classes_Must_Go_Online_T eaching_Activities_and_Challenges_during_COVID-19_Pandemic_in_Indonesia

Nurazizah, H., Frihatin, L. Y., \& Sugiarto, B. R. (2019). Whatsapp VoiceNote in Speaking Class. Journal of English Education and Teaching (JEET), 3(3).

Plana, M. G.-C., Escofet, M. I. G., Figueras, I. T., Gimeno, A., Appel, C., \& Hopkins, J. (2013). 
Improving learners' reading skills through instant short messages: A sample study using WhatsApp. 4th World-CALL Conference, Glasgow.

Raad, B. (2020). The Role of E-Learning in Covid-19. International Journal of Creative Research Thought, 8(3), 3135-3138.

Sahidillah, M. W., \& Miftahurrisqi, P. (2019). Whatsapp sebagai Media Literasi Digital Siswa. Jurnal Varidika, 3(1), 52-57.

Sari, F. M. (2020). Exploring English Learners' Engagement and Their Roles in the Online Language Course. Journal of English Language Teaching and Linguistics, 5(3). Retrieved from https://jeltl.org/index.php/jeltl/article/view/446

Shodiq, I. J., \& Zainiyati, H. S. (2020). Pemanfaatan Media Pembelajaran E-Learning menggunakan whastsapp Sebagai Solusi Ditengah Penyebaran Covid-19 di Ml Nurulhuda Jelu. Al-Insyiroh: Jurnal Studi Keislaman, 6(2).

Suyudi, A., Khusaini, K., Sugiyanto, \& Winarto, W. (2017). Penggunaan WhatsApp dalam Perkuliahan Penilaian Pendidikan Fisika. Jurnal Riset Dan Kajian Pendidikan Fisika. Retrieved from 4. 10.12928/jrkpf.v4i1.6462. 